\title{
Importance of copepods versus appendicularians in vertical carbon fluxes in a Swedish fjord
}

\author{
Cristian A. $\operatorname{Vargas}^{1, *}$, Kajsa Tönnesson ${ }^{1}$, Anne Sell $^{1, * *}$, Marie Maar $^{2}$, Eva Friis Møller $^{2}$, \\ Tania Zervoudaki ${ }^{3}$, Antonia Giannakourou ${ }^{3}$, Epaminondas Christou ${ }^{3}$, \\ Suree Satapoomin ${ }^{4}$, Jens Kjerulf Petersen ${ }^{2}$, Torkel Gissel Nielsen ${ }^{2}$, Peter Tiselius ${ }^{1}$ \\ ${ }^{1}$ Göteborg University, Kristineberg Marine Research Station, 45034 Fiskebäckskil, Sweden \\ ${ }^{2}$ National Environmental Research Institute, Department of Marine Ecology, PO Box 358, 4000 Roskilde, Denmark \\ ${ }^{3}$ National Centre for Marine Research, 16604 Hellenikon, Athens, Greece \\ ${ }^{4}$ Phuket Marine Biological Center, PO Box 60, Phuket 83000, Thailand
}

\begin{abstract}
We examined and quantified the contributions of copepods and appendicularians to the vertical flux of carbon during autumn and spring in Gullmar Fjord (west coast of Sweden). Faecal pellet-production rate was determined for major copepod and appendicularian species. In addition, house-production rates were estimated for the appendicularian Oikopleura dioica. Vertical flux of pigments, faecal carbon and appendicularian houses were measured using short-term $(24 \mathrm{~h})$ deployments of sediment traps at 2 depths $(15$ and $30 \mathrm{~m})$. Copepods dominated the community biomass in both spring and autumn and their pellets dominated the faecal carbon flux. O. dioica houses with attached detritus were an important component of the biogenic carbon flux in October $\left(15.3 \mathrm{mg} \mathrm{C} \mathrm{m}^{-2} \mathrm{~d}^{-1}\right)$, equalling the contribution from copepods at $15 \mathrm{~m}$ and $50 \%$ of the flux at $30 \mathrm{~m}$. At that time, we observed a loss rate of $70 \% \mathrm{~d}^{-1}$ of the houses produced in the water column. In the spring, although Fritillaria borealis dominated the appendicularians, its houses did not appear to contribute to the biogenic flux. Our results suggest that oikopleurids and fritillariids may not operate equivalently in biogeochemical cycles. Because of the significant contribution of appendicularians to carbon fluxes, they should be incorporated in future flow models of coastal oceans
\end{abstract}

KEY WORDS: Carbon flux $\cdot$ Appendicularians $\cdot$ Copepods $\cdot$ Faecal pellet production $\cdot$ Marine snow Resale or republication not permitted without written consent of the publisher

\section{INTRODUCTION}

Productive coastal areas are characterised by a significant export of biogenic carbon to the bottom, and the structure of pelagic ecosystems influences the magnitude and quality of this flux (Petersen \& Curtis 1980, Peinert et al. 1989, Legendre \& Rassoulzadegan 1996). One of the most important mechanisms by

Present addresses:

${ }^{*}$ Doctoral Program in Oceanography, Department of Oceanography, Universidad de Concepcion, PO Box 160-C, Concepcion, Chile.E-mail: crvargas@udec.cl

**Biology Department, Woods Hole Oceanographic Institution, Woods Hole, Massachusetts 02543, USA which carbon is transported from the euphotic layer to the sea floor is the vertical flux of zooplankton faecal pellets and large organic aggregates, commonly referred to as marine snow (Alldredge \& Silver 1988, Walsh \& Gardner 1992, Syvitski et al. 1995). These aggregates can be formed directly from phytoplankton through aggregation processes (Kiørboe et al. 1994) or from flocculation of faecal pellets and discarded mucous feeding webs of some zooplankton (Alldredge \& Gotschalk 1988).

Appendicularians produce such mucous feeding structures or 'houses' (Flood \& Deibel 1998) to filter bacteria, small algae and other particles from the surrounding water. Appendicularians can process large amounts of food in a short time, and their wastes are 
extruded in short time intervals as faecal pellets (López-Urrutia \& Acuña 1999). Some of these faecal pellets, together with uneaten particles, eventually clog the house, which is then abandoned and replaced by a new house, approximately 4 to 6 times per day (Deibel 1988, Alldredge 1992, Hansen et al. 1996, Sato et al. 2001). Thus, appendicularian houses together with their faecal pellets may constitute an important component of marine snow (Alldredge \& Gotschalk 1990, Hansen et al. 1996). Furthermore, due to the high efficiency with which appendicularians ingest nanoplankton and picoplankton (King et al. 1980, Deibel 1988, Deibel \& Lee 1992, Acuña et al. 1996), they constitute a pathway through which small cells that otherwise do not sink may be transported out of the euphotic zone. Consequently, when appendicularians are abundant, small phytoplankton cells may contribute much more to the vertical flux than when the community is dominated by copepods (Urban et al. 1992, Hansen et al. 1996).

Oikopleura and Fritillaria species are abundant pelagic tunicates in coastal waters (e.g. Acuña et al. 1995, Hopcroft \& Roff 1998, Gorsky et al. 2000). On the western Norwegian coast, O. dioica is one of the most widely distributed species (Gorsky et al. 2000). In the Kattegat, appendicularians also represent an important component of the zooplankton community during the autumn and spring blooms (Nielsen \& Hansen 1999). The abundance of copepods in these boreal waters suggests that their faecal pellets may also be an important component of the downward flux of biogenic carbon (Lindahl 1990). However, appendicularians can show higher growth rates than copepods in response to an increase in food (Hopcroft \& Roff 1995, Hopcroft et al. 1998), and they should therefore account for a significant removal of primary producers through graz-

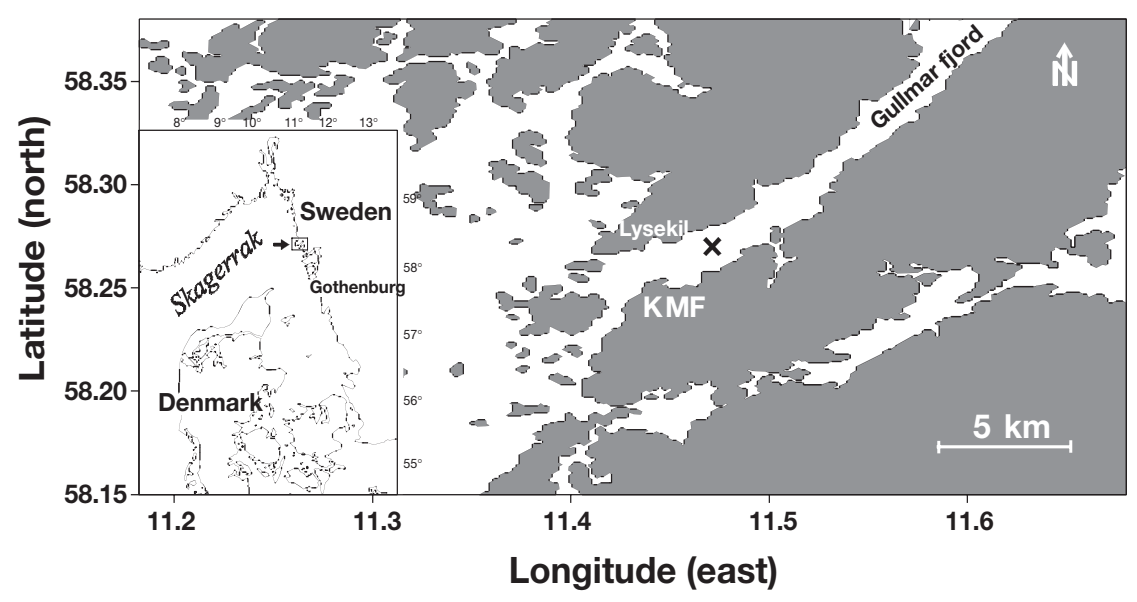

Fig. 1. Map of study area with the position of sampling station $(x)$ KMF: Kristineberg Marine Research Station ing. Consequently, short-term shifts in the zooplankton community structure may affect the particle flux in this environment.

Most studies of zooplankton-mediated fluxes in coastal and oceanic areas have only been able to identify the combined contribution of copepods or appendicularians to the faecal flux (as measured in sediment traps) (e.g. Taguchi 1982, Gonzalez et al. 1994, 2000, Landry et al. 1994). In order to unravel the contribution of the different pathways by which primary production moves through the pelagic food web, species-specific analyses are needed. The present study examines and quantifies the contribution of appendicularian faecal pellets and discarded mucous houses to the vertical flux of carbon in a Swedish fjord during autumn and spring. It also compares the potential faecal fluxes produced by appendicularians, by different copepod species and by direct algal sinking (measured from pigments).

\section{MATERIALS AND METHODS}

Study area. The study was conducted in Gullmar Fjord, in the archipelago of the NW coast of Sweden in the Skagerrak $\left(58^{\circ} 18.6^{\prime} \mathrm{N}, 1^{\circ} 32.4^{\prime} \mathrm{E}\right.$; Fig. 1) during 2 periods: 14 to 15 October 1999 and 7 to 14 March 2000. The Gullmar Fjord is $30 \mathrm{~km}$ long and $3 \mathrm{~km}$ wide with a maximum depth of $120 \mathrm{~m}$ and a sill depth of $45 \mathrm{~m}$. All sampling was conducted at a $60 \mathrm{~m}$ deep station close $(\sim 3$ to $5 \mathrm{~km})$ to the mouth of the fjord.

Sampling scheme. During October, sampling was done approximately every $6 \mathrm{~h}$ between 09:00 (14 October) and 13:00 h (15 October). On 7, 8, 9, 10, 13 and 14 March, samples were taken every morning between 08:00 and 10:00 h. On each sampling occasion, vertical profiles of temperature, salinity, density, and fluorescence were recorded with a CTD-rosette (Neil Brown) with HydroBios water bottles equipped with a fluorescence sensor (Sea Bird). Vertical net hauls for zooplankton were done in 4 layers of the water column using a WP-2 net with $200 \mu \mathrm{m}$ (October) or $90 \mu \mathrm{m}$ (March) mesh size, closing devices and a calibrated General Oceanic flowmeter. The depth strata chosen in both periods were $0-10$; $10-20 ; 20-30 \mathrm{~m}$ and from $30 \mathrm{~m}$ to the bottom (at approx. 55 to $60 \mathrm{~m}$ ). Samples were preserved immediately after collection in 5\% buffered formalin. Zooplankton analysis involved the identification of a minimum of 1000 animals in each of the quantitative subsamples. 
Phytoplankton pigments were measured from the water samples collected at 2, 5, 10, 15, 20 and $30 \mathrm{~m}$ depth. Chlorophyll $a$ and phaeopigments were extracted for $24 \mathrm{~h}$ in $96 \%$ ethanol (Jespersen \& Christoffersen 1987) and analysed fluorometrically (Turner Design fluorometer; Strickland \& Parsons 1968). Primary productivity was measured on 14 October and 8, 9 and 14 March using the in situ ${ }^{14} \mathrm{C}$-technique according to the protocol of the Pelagic Monitoring Group at Kristineberg Marine Research Station (see Lindahl 1995).

Zooplankton faecal pellet and appendicularian house production experiments. The copepods and appendicularians used in the experiments were collected from vertical net hauls with a $90 \mu \mathrm{m}$ mesh net with a large, non-filtering cod end (40 to 60 l). Immediately after collection, the animals were diluted in filtered surface seawater. Appendicularians were carefully isolated with a wide-mouthed pipette and the dominant stages of copepods were selected under a dissecting microscope after concentration. Water for incubation was collected from $10 \mathrm{~m}$ depth and prescreened through a $90 \mu \mathrm{m}$ sieve. For each experiment, 4 control bottles without animals and 4 bottles with 4 animals each were placed on a plankton wheel at $0.2 \mathrm{rpm}$ for $24 \mathrm{~h}$ at $12^{\circ} \mathrm{C}$ (October) and $5^{\circ} \mathrm{C}$ (March). Care was taken to ensure each $620 \mathrm{ml}$ bottle was completely devoid of air bubbles.

After incubation, the bottles were removed from the wheel and the contents were gently poured through a $20 \mu \mathrm{m}$ sieve to collect animals, faecal pellets, and appendicularian houses. Most of these fragile animals were healthy and actively filtering after the $24 \mathrm{~h}$ incubation. The length and width of 25 pellets per bottle were measured and their volume estimated assuming that copepod faeces have a cylindrical shape and appendicularian faeces an ellipsoidal shape (González et al. 1994). Faecal pellets from each species were preserved and later photographed to identify the origin of the faecal pellets collected in the sediment trap. A few very small spherical pellets $(\sim 20 \times 20 \mu \mathrm{m})$, possibly originating from dinoflagellates (Gowing \& Silver 1985, González 1992) or other zooplankton, were occasionally found in the samples but were not taken into account in this study. An approximation for the carbon content of aggregates derived from appendicularian houses was calculated using equations suggested by Alldredge (1998). The faecal pellet production rate was calculated by subtracting the number of faecal pellets found in the control bottles from those in experimental bottles and dividing by the incubation time. We assumed that coprophagy was minimal. The carbon content of copepod and appendicularian pellets was calculated using the ratios 0.042 and $0.057 \mathrm{mgC} \mathrm{mm}^{-3}$, respectively, reported by González et al. (1994) for
Bjørnafjoden, Norway. The carbon content of fresh appendicularian houses was estimated to be $15.3 \%$ of body carbon (Sato et al. 2001). Ash-free dry weight (AFDW, $\mu \mathrm{g}$ ) was estimated from individual trunk lengths by using the length-weight-regression equation given by Paffenhöfer (1976). The carbon-based biomass of Oikopleura dioica was then calculated from numerical abundance and trunk-length distributions within the population, using the carbon ( $\mu \mathrm{g} C)$-dry weight $(\mu \mathrm{g})$ regression suggested by Gorsky et al. (1988). To estimate the potential daily carbon flux through sedimentation of houses and faecal pellets, the average individual house and faecal carbon production ( $\mu \mathrm{g} \mathrm{C}$ ind.$^{-1} \mathrm{~d}^{-1}$ ) was multiplied by the abundance (ind. $\mathrm{m}^{-3}$ ) of the animals in each stratum sampled.

During October, faecal pellet production was estimated for the copepods Acartia clausi, Paracalanus parvus and Centropages hamatus, and the appendicularian Oikopleura dioica. Estimates in March included A. clausi, Pseudocalanus elongatus, Temora longicornis, and Oithona similis. We were, however, unable to collect undamaged the Fritillaria borealis that dominated in March, and consequently could not measure their house- or pellet-production rate.

Sedimentation rates of houses, faecal pellets, and phytoplankton pigments. The vertical flux of zooplankton faecal pellets and appendicularian houses was measured at 2 arrays (distance between moorings $\approx 100 \mathrm{~m}$ ). Sediment traps (inner diameter $80 \mathrm{~mm}$, height $555 \mathrm{~mm}$, no baffles) were deployed at 15 and $30 \mathrm{~m}$ depth in each of 2 arrays for approximately $24 \mathrm{~h}$. The traps were filled with $0.5 \mu \mathrm{m}$-filtered water from $30 \mathrm{~m}$ depth before deployment and no preservative was added. Following recovery of the array, the trap contents were carefully poured into a plastic bottle, carefully homogenised, and a $20 \mathrm{ml}$ subsample was taken to determine the concentration of chlorophyll a and phaeopigments (see above). The remaining sample was preserved with $10 \%$ formalin for faecal pellet and house counts.

We calculated the proportion of the total phaeopigments that correspond to faecal pellets assuming a carbon:phaeopigment ratio of 15, typical of a grazing season (Newton Downs \& Lorenzen 1985, Thibault et al. 1999). The remaining phaeopigments we assigned to other sources, such as micropellets from other zooplankton taxa species or senescent phytoplankton. The relationship between faecal fluxes, pigment fluxes and water-column phytoplankton productivity and biomass was investigated by comparing the inputs of chlorophyll a (chl $a$, representing phytoplankton) and phaeopigments (representing faecal pellets and senescent algae) in the traps to the chl a biomass and primary production in the upper layer (0 to $30 \mathrm{~m}$ ). To assess the relative proportion of the integrated (i.e. over the $60 \mathrm{~m}$ 
Fig. 2. Hydrographic conditions during sampling periods. (a) Mean temperature profile on 14 and 15 October 1999; $(\mathrm{b}, \mathrm{c})$ vertical distribution of chlorophyll a (mg chl a $\mathrm{m}^{-3}$, shaded area) and salinity (PSU, isoline curves) on 14 and 15 October 1999 (b) and 7 to 14 March 2000 (c); (d) chlorophyll a:phaeopigment ratio (shaded area) and temperature $\left({ }^{\circ} \mathrm{C}\right.$, isoline curves) from 7 to 14 March 2000; $(\bullet),(\times)$ data points for hydrography and pigments, respectively

water column) primary production (PP) that sedimented as pigmented particles, the concentrations of chl $a$ and phaeopigments in the traps were converted to concentrations of $\mathrm{C}$, assuming a $\mathrm{C}: \mathrm{chl}$ a ratio of 50 (Booth et al. 1993) and a C:phaeopigments ratio of 15 (taking the assimilation efficiency to be $70 \%$ on average; Thibault et al. 1999) (see Table 4).

\section{RESULTS}

\section{Chlorophyll a}

From 14 to 15 October, the water column was thermally homogeneous with temperatures of 13 to $15^{\circ} \mathrm{C}$ in the upper $40 \mathrm{~m}$ (Fig. 2a). A halocline was located at 5 to $10 \mathrm{~m}$ (29.5 to 31.5 PSU: Fig. 2b). Chl a concentrations were highest in the upper mixed $10 \mathrm{~m}$, varying between 1.4 and $2.2 \mathrm{mg} \mathrm{chl} \mathrm{a} \mathrm{m} \mathrm{m}^{-3}$ (Fig. 2b).

In March, a less marked halocline was observed (Fig. 2c). On 7 March we found moderate subsurface concentrations of $\left.\mathrm{chl} \mathrm{a} \mathrm{(1.2} \mathrm{to} 1.7 \mathrm{mg} \mathrm{chl} \mathrm{a} \mathrm{m}^{-3}\right)$, which decreased on 9 and 10 March. Finally, chl $a$ in the surface layer began to increase exponentially on 13 and 14 March from 1.0 to $3.0 \mathrm{mg} \mathrm{chl} \mathrm{a} \mathrm{m}^{-3}$. The vertical distribution of the chla:phaeopigments ratio showed a high proportion of phaeopigments between 20 and $30 \mathrm{~m}$ depth on 7 March (Fig. 2d). This suggests that either phytoplankton senescence, accumulation of small pellets, or changes in the composition of the phytoplankton community occurred at depth.

\section{Zooplankton abundance and vertical distribution}

Copepods were the numerically dominant members of the zooplankton community in the study area. The small copepods, Acartia clausi, Paracalanus parvus, Pseudocalanus elongatus and Oithona similis predominated during both sampling periods (Table 1). Larger
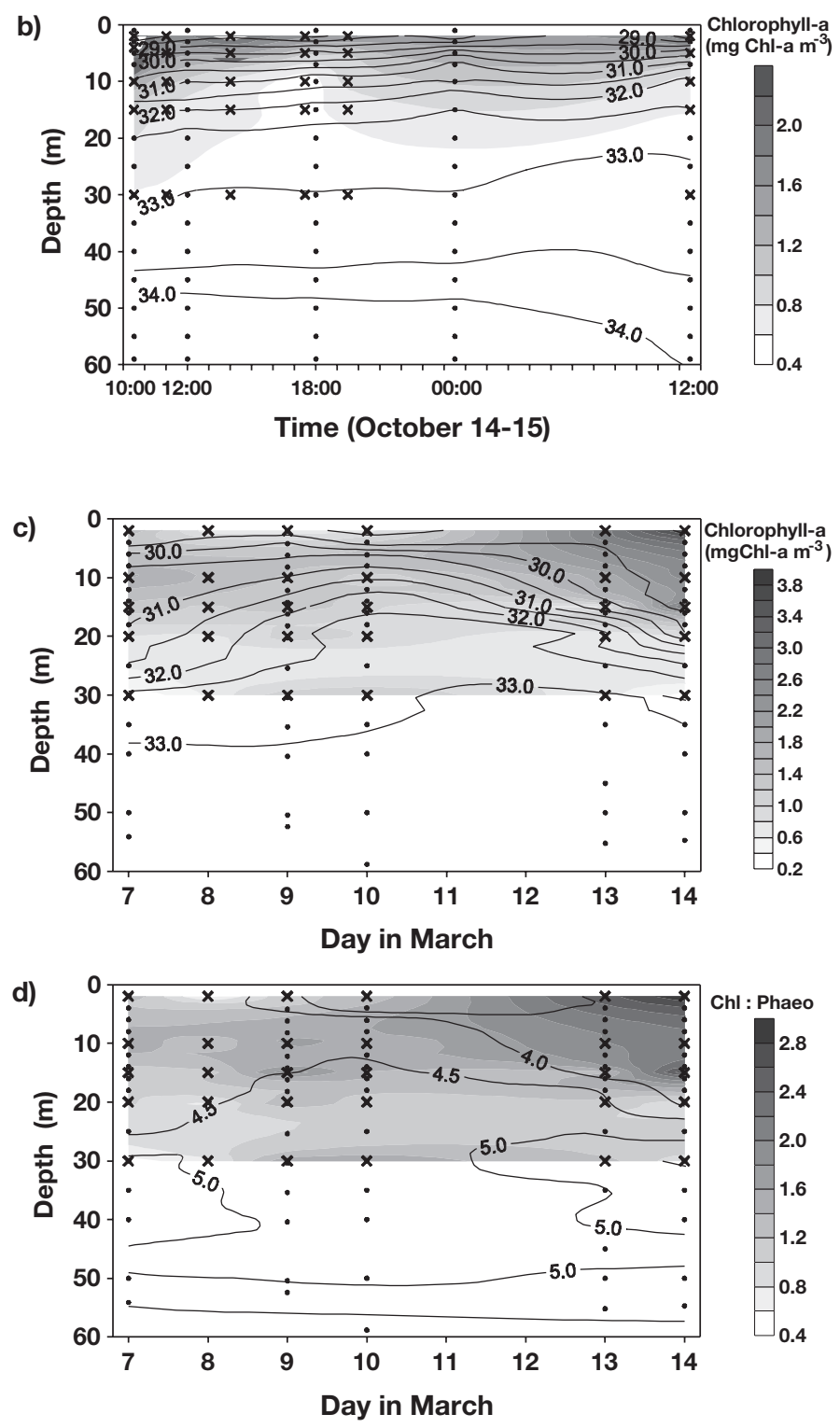

copepods (e.g. Calanus finmarchicus) were slightly more abundant during March than during October (unpaired $t$-test, 1 -tailed; $\mathrm{df}=16 ; \mathrm{p}=0.021$ ). The cyclopoid copepod Corycaeus anglicus was relatively abundant in the samples from October (3667 ind. $\mathrm{m}^{-2}$ ). Oikopleura dioica was abundant in October (4069 \pm 1513 ind. $\mathrm{m}^{-2}$ ), whereas Fritillaria borealis dominated in March (6736 \pm 12922 ind. $\mathrm{m}^{-2}$ : Table 1).

In October, the highest copepod abundance was in the peak chlorophyll surface layer (Table 1). In contrast, during March most of the copepods and the appendicularian Fritillaria borealis were concentrated in the subsurface stratum (10 to $20 \mathrm{~m}$ : Table 1). In spring, integrated biomass was relatively low during the first days of sampling, increasing notably on 13 March (Fig. 3). 


\section{Faecal pellet and appendicularian house production}

During October, the mean daily faecal pellet production for copepods ranged between 1.1 and 1.6 pellets ind. ${ }^{-1} \mathrm{~h}^{-1}$ (Table 2A). Acartia clausi and Paracalanus parvus produced small pellets $\left(0.6\right.$ and $1.8 \times 10^{5} \mu^{3}$ respectively) while Centropages hamatus produced

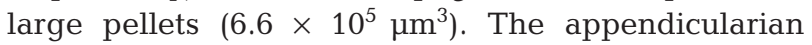
Oikopleura dioica produced a high number of small pellets (147 pellets ind.$\left.^{-1} \mathrm{~d}^{-1}\right)$, similar in size $(0.9$ to 1.8 $\times 10^{5} \mathrm{\mu m}^{3}$ ) to those of A. clausi. O. dioica produced 5.0 houses ind.$^{-1} \mathrm{~d}^{-1}\left(0.2\right.$ houses ind.$^{-1} \mathrm{~h}^{-1}$, Table $\left.2 \mathrm{~A}\right)$. Car-

Table 1. Average (SD) abundance (nos.) of mesozooplankton taxa collected from 4 different strata in the Gullmar Fjord during October 1999 and March 2000. Integrated abundance (ind. $\mathrm{m}^{-2}$ ) over the upper $60 \mathrm{~m}$ water column is also shown. Total number of plankton tows in the 4 different strata was 5 and 4 during the 2 sampling periods, respectively

\begin{tabular}{|c|c|c|c|c|c|}
\hline \multirow[t]{2}{*}{ Taxon } & \multicolumn{4}{|c|}{ Stratum (m) } & \multirow{2}{*}{$\begin{array}{l}\text { Integrated } \\
\text { abundance }\end{array}$} \\
\hline & $0-10$ & $10-20$ & $20-30$ & $30-55$ & \\
\hline \multicolumn{6}{|l|}{ OCTOBER 1999} \\
\hline \multicolumn{6}{|l|}{ Small copepods } \\
\hline Acartia clausi & $252(76)$ & $55(36)$ & $40(44)$ & $17(15)$ & 3892 (911) \\
\hline Paracalanus parvus & $444(53)$ & $86(51)$ & $102(113)$ & $89(68)$ & 8565 (2954) \\
\hline Pseudocalanus elongatus & $91(34)$ & $11(3)$ & $21(17)$ & $43(22)$ & $2313(692)$ \\
\hline Microcalanus pusillus & 0 & 0 & $0.1(0.1)$ & $3(2)$ & $74(41)$ \\
\hline Temora longicornis & $8(14)$ & $0.3(0.3)$ & $0.1(0.2)$ & $0.05(0.09)$ & 87 (137) \\
\hline Eurytemora affinis & 0 & 0 & 0 & 0 & 0 \\
\hline Oithona similis & $3232(2328)$ & $959(1057)$ & $326(245)$ & $283(121)$ & 52249 (35 463) \\
\hline Oncaea sp. & 0 & 0 & 0 & 0 & 0 \\
\hline Corycaeus anglicus & $214(138)$ & $85(67)$ & $56(43)$ & $4(2)$ & 3667 (2209) \\
\hline Microsetella norvegica & $10(18)$ & 0 & 13 (18) & $14(14)$ & 580 (729) \\
\hline Total & & & & & 71427 \\
\hline \multicolumn{6}{|l|}{ Medium-large copepods } \\
\hline Calanus finmarchicus & $7(9)$ & $4(5)$ & $4(1)$ & $13(0.6)$ & $473(149)$ \\
\hline Metridia lucens & 0 & 0 & 0 & 0 & 0 \\
\hline Centropages hamatus & $6(4)$ & $3(3)$ & $2(3)$ & 0 & $102(54)$ \\
\hline Total & & & & & 575 \\
\hline \multicolumn{6}{|l|}{ Appendicularians } \\
\hline Oikopleura dioica & $296(74)$ & $64(47)$ & $30(22)$ & $7(3)$ & 4069 (1513) \\
\hline Fritillaria borealis & 0 & 0 & 0 & 0 & 0 \\
\hline Total & & & & & 4069 \\
\hline \multicolumn{6}{|l|}{ MARCH 2000} \\
\hline \multicolumn{6}{|l|}{ Small copepods } \\
\hline Acartia clausi & $62(68)$ & 74 (103) & $58(16)$ & $1(1)$ & 1565.7 (1689.0) \\
\hline Paracalanus parvus & 380 (209) & 404 (448) & $27(14)$ & $190(89)$ & $14981.5(5812.1)$ \\
\hline Pseudocalanus elongatus & $15(10)$ & $30(37)$ & $7(5)$ & 76 (35) & 2611.9 (1383.9) \\
\hline Microcalanus pusillus & 0 & $4(4)$ & $1(2)$ & $9(2)$ & $337.0(87.1)$ \\
\hline Temora longicornis & $93(87)$ & $72(70)$ & $2(4)$ & $50(38)$ & $3346.3(1661.7)$ \\
\hline Eurytemora affinis & $4(5)$ & $0.7(1)$ & $2(4)$ & 0 & $66.6(47.3)$ \\
\hline Oithona similis & 139 (12) & $131(94)$ & $240(17)$ & $32(32)$ & $4082.1(1700.8)$ \\
\hline Oncaea sp. & 0 & $7(14)$ & $2(4)$ & $3(2)$ & 240.8 (318.6) \\
\hline Corycaeus anglicus & $1(2)$ & $15(28)$ & $9(15)$ & $2(1)$ & $210.7(320.2)$ \\
\hline Microsetella norvegica & $19(14)$ & $26(39)$ & 0 & $37(27)$ & $1777.2(1412.9)$ \\
\hline Total & & & & & 29219.8 \\
\hline \multicolumn{6}{|l|}{ Medium-large copepods } \\
\hline Calanus finmarchicus & $55(82)$ & $48(73)$ & $47(22)$ & $16(10)$ & $1684.8(1562.3)$ \\
\hline Metridia lucens & 0 & 0 & $40(28)$ & $1(1)$ & $57.9(45.1)$ \\
\hline Centropages hamatus & 0 & 0 & 0 & 0 & 0 \\
\hline Total & & & & & 1742.7 \\
\hline \multicolumn{6}{|l|}{ Appendicularians } \\
\hline Oikopleura dioica & 0 & 0 & $0.8(1)$ & 0 & $437.6(681.0)$ \\
\hline Fritillaria borealis & $19(28)$ & $24(41)$ & $10(8)$ & 0 & 6736.7 (12 922.1) \\
\hline Total & & & & & 7174.3 \\
\hline
\end{tabular}



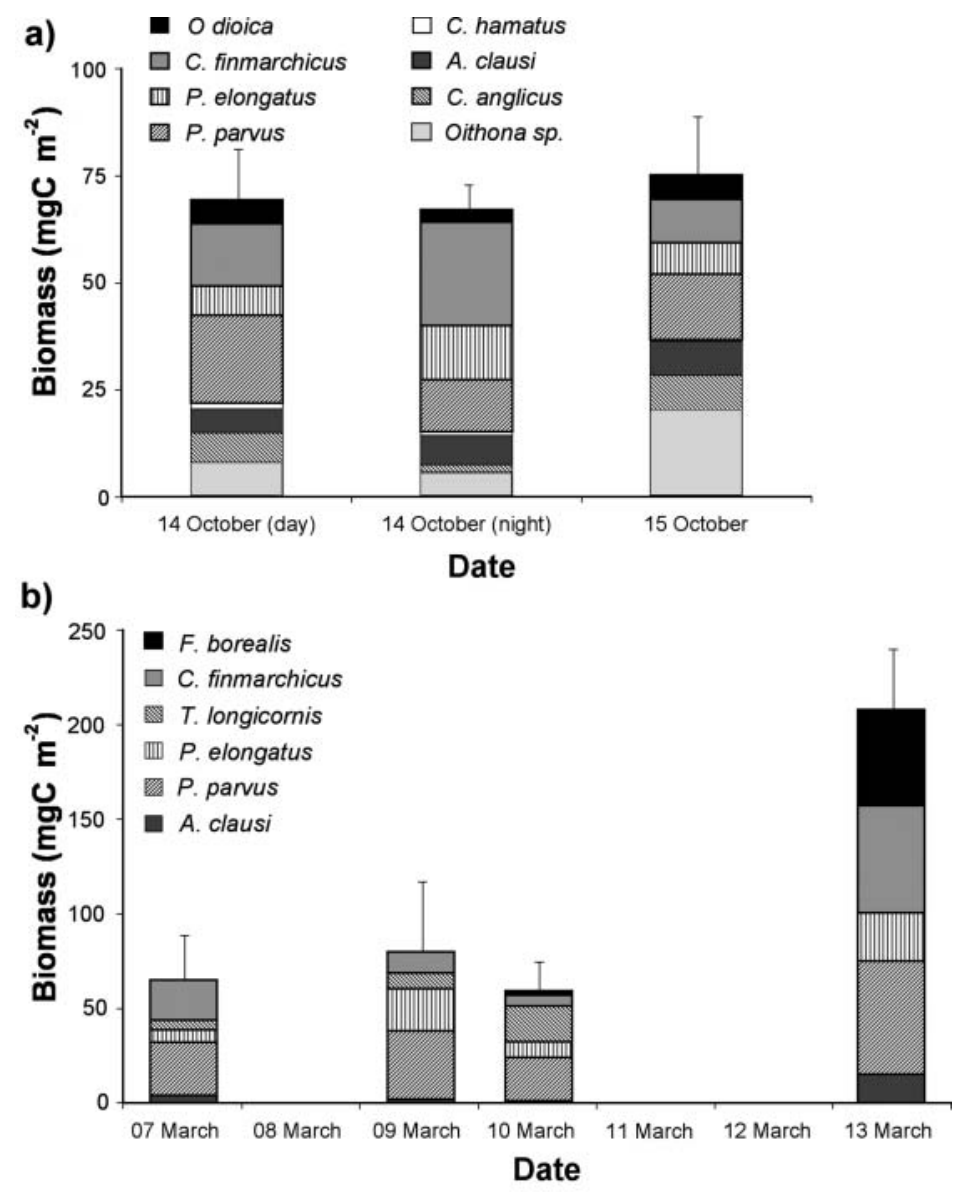

Fig. 3. Integrated biomass of the predominant zooplankton species over the $60 \mathrm{~m}$ water column in the Gullmar Fjord from 7 to 13 March $2000\left(\mathrm{mg} \mathrm{C} \mathrm{m}^{-2}\right)$. Note different scales of $y$-axis. Error bars are standard deviations. Full specific names are given in Table 1 bon production by $O$. dioica during October was 3.7 and $6.6 \mathrm{mg} \mathrm{C} \mathrm{m}^{-2} \mathrm{~d}^{-1}$, for faecal pellets and houses, respectively (Table 3 ). The estimated potential vertical flux of carbon due to the dominant copepods studied (12559 ind. $\mathrm{m}^{-2}$ ) totalled $6 \mathrm{mg} \mathrm{C} \mathrm{m}^{-2} \mathrm{~d}^{-1}$ (Table 3$)$.

Individual faecal pellet production rate was relatively homogeneous throughout the study period in March (Table 2B). Acartia clausi made the lowest contribution to the total faecal pellet production of the species studied (Table 3), producing fewer pellets in March than in October (0.6 and 1.3 pellets ind. ${ }^{-1} \mathrm{~h}^{-1}$, respectively) (paired $t$-test; 1-tailed; df $=12 ; \mathrm{p}=0.0485$ ). Pseudocalanus elongatus and Temora longicornis had the highest faecal production rates in spring (1.8 and 1.3 pellets ind.$^{-1} \mathrm{~h}^{-1}$, respectively). T. longicornis produced large faecal pel-

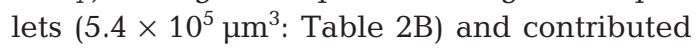
most to the faecal carbon production in the water column (Table 3). Oithona similis produced few and very small pellets $\left(0.3\right.$ pellets ind.$^{-1} \mathrm{~h}^{-1}$ / $0.2 \mu^{3} \times 10^{5}$ : Table $\left.2 \mathrm{~B}\right)$ that were probably recycled in the water column (González \& Smetacek 1994).

\section{Downward flux of biogenic carbon}

Microscopical analysis of the sedimented matter showed faecal pellets of different origin (copepods, appendicularians, euphausiids and unidentified) and marine snow aggregates

Table 2. Mean (SD) faecal pellet production rate (FPP) (faeces ind.$^{-1} \mathrm{~h}^{-1}$ ) and faecal pellet volume $\left(\mu \mathrm{m}^{3} \times 10^{5}\right)$ for abundant taxa collected during 14 and 15 October 1999 (A) and from 7 to 13 March 2000 (B). House production rate (HP) (houses ind. ${ }^{-1} \mathrm{~h}^{-1}$ ) of Oikopleura dioica is also included for October 1999. Number of experimental replicates on each occasion were generally 4 in October and 3 in March. Approximately 25 to 30 pellets were measured per incubation bottle

\begin{tabular}{|c|c|c|c|c|c|}
\hline \multirow[t]{2}{*}{ (A) OCTOBER 1999} & \multirow[t]{2}{*}{ Acartia clausi } & \multirow[t]{2}{*}{ Paracalanus parvus } & \multirow[t]{2}{*}{ Centropages hamatus } & \multicolumn{2}{|c|}{ Oikopleura dioica } \\
\hline & & & & FPP & HP \\
\hline 14 Oct (day) & $1.8(3.4)$ & $2.4(1.7)$ & $2.4(1.9)$ & $2.7(2.2)$ & $0.3(0.3)$ \\
\hline (night) & $1.5(1.7)$ & $0.4(0.8)$ & $0.3(0.8)$ & $4.8(1.0)$ & $0.2(0.03)$ \\
\hline 15 Oct (day) & $0.6(0.8)$ & $1.9(0.9)$ & $0.5(0.4)$ & $12.2(4.8)$ & $0.2(0.1)$ \\
\hline Mean FPP and HP rate & $1.3(0.6)$ & $1.6(0.4)$ & $1.1(1.2)$ & $8.1(3.8)$ & $0.2(0.1)$ \\
\hline Mean FP volume & $1.8(0.01)$ & $0.6(0.001)$ & $6.6(0.1)$ & $1.3(5.5)$ & \\
\hline (B) MARCH 2000 & Acartia clausi & Pseudocalanus elongatus & Temora longicornis & \multicolumn{2}{|c|}{ Oithona similis } \\
\hline 07 Mar & $0.7(0.1)$ & $1.9(1.2)$ & $2.6(0.2)$ & \multicolumn{2}{|c|}{$0.4(0.2)$} \\
\hline 09 Mar & $0.7(0.2)$ & $1.6(0.4)$ & $0.8(0.2)$ & \multicolumn{2}{|c|}{$0.1(0.03)$} \\
\hline $10 \mathrm{Mar}$ & $0.3(0.2)$ & $2.3(1.1)$ & $0.6(0.1)$ & \multicolumn{2}{|c|}{$0.3(0.2)$} \\
\hline 13 Mar & $0.5(0.3)$ & $1.2(0.4)$ & $1.3(0.5)$ & \multicolumn{2}{|c|}{$0.3(0.2)$} \\
\hline Mean FPP rate & $0.6(0.2)$ & $1.8(0.5)$ & $1.3(0.9)$ & \multicolumn{2}{|c|}{$0.3(0.1)$} \\
\hline Mean FP volume & $1.5(0.1)$ & $1.9(0.001)$ & $5.4(0.6)$ & \multicolumn{2}{|c|}{$0.2(0.01)$} \\
\hline
\end{tabular}


(Fig. 4). We identified the genera producing most of the faecal pellets among the copepods as Acartia, Pseudocalanus, Temora, Calanus and Oithona, apart from the appendicularians Oikopleura and Fritillaria. Although there were occasionally differences in the composition of the 2 arrays of traps (Fig. 5), overall both arrays performed similarly, with no significant differences in total flux between arrays at either collection depth (paired $t$-tests; 2-tailed; df $=71 ; \mathrm{p}=$ 0.058).

In October, sediment trap material consisted of aggregates derived from appendicularian houses with attached amorphous detritus, faecal pellets and phytoplankton cells (Fig. 5b). The flux of houses decreased with increasing depth and was on average 8400 and 5800 houses $\mathrm{m}^{-2} \mathrm{~d}^{-1}$ at 15 and $30 \mathrm{~m}$ depth, respectively, representing 24.5 and $15.8 \mathrm{mg} \mathrm{C} \mathrm{m}^{-2} \mathrm{~d}^{-1}$, respectively
Table 3. Mean $( \pm \mathrm{SD})$ carbon production $\left(\mathrm{mg} \mathrm{C} \mathrm{m}^{-2} \mathrm{~d}^{-1}\right)$ of zooplankton faeces and appendicularian houses integrated over the water column ( 0 to $50 \mathrm{~m}$ ) in Gullmar Fjord during October 1999 and March 2000. Number of experiments = 3 in October and 5 in March. The carbon content of appendicularian houses was estimated to be $15.3 \%$ body carbon (Sato et al. 2001)

\begin{tabular}{|lcc|}
\hline Species & October 1999 & March 2000 \\
\hline Acartia clausi & $2.5 \pm 0.9$ & $0.3 \pm 0.3$ \\
Paracalanus parvus & $2.2 \pm 0.7$ & nd \\
Centropages hamatus & $1.3 \pm 0.5$ & nd \\
Oikopleura dioica $(O . d)$. & $3.7 \pm 1.7$ & nd \\
(O. d. house production) & $6.6 \pm 0.3$ & nd \\
Pseudocalanus elongatus & nd & $2.0 \pm 0.6$ \\
Temora longicornis & nd & $2.9 \pm 0.4$ \\
Oithona similis & nd & $0.03 \pm 0.01$ \\
Total copepod & 6.0 & 5.23 \\
Total appendicularians & 10.3 & \\
\hline
\end{tabular}

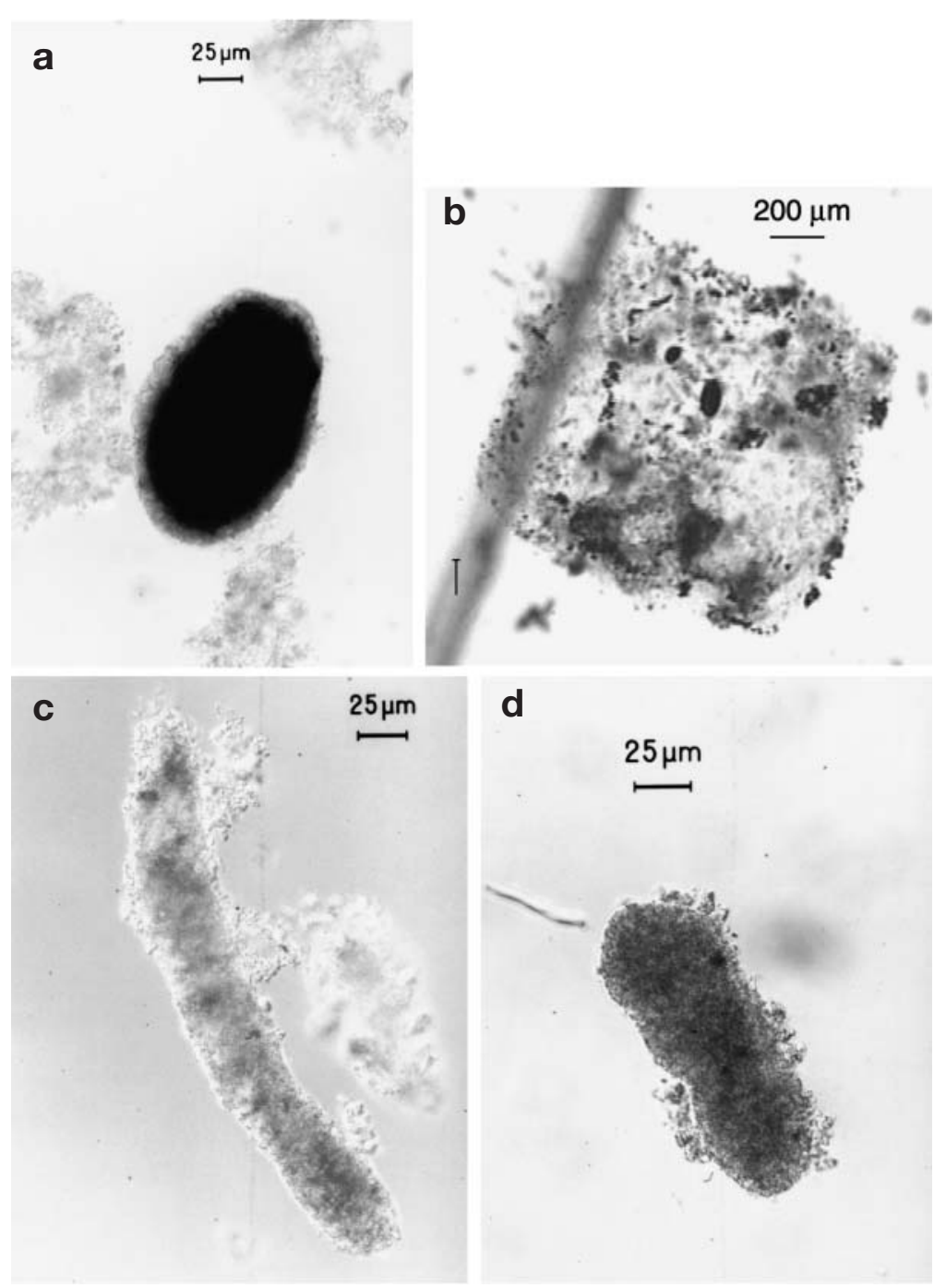

Fig. 4. Inverted microscope photographs of the various types of material found in the sediment traps: (a) appendicularian pellets; (b) oikopleurid houses; (c) Pseudocalanus elongatus; (d) Acartia clausi pellets
(Fig. 5a,b). Total sedimented faecal matter was, on average, almost twice as high at $30 \mathrm{~m}\left(37 \mathrm{mg} \mathrm{C} \mathrm{m}^{-2} \mathrm{~d}^{-1}\right)$ as at $15 \mathrm{~m}$ depth (22 $\mathrm{mg} \mathrm{C} \mathrm{m}^{-2} \mathrm{~d}^{-1}$ ) (Fig. 5a,b) (Wilcoxon test; $\mathrm{n}=18 ; \mathrm{p}=0.034)$. Unidentified copepod pellets dominated in October, but otherwise faecal pellets from Pseudocalanus elongatus and the appendicularian Oikopleura dioica gave the highest individual species contribution to the total faecal carbon flux (8.3 and $3.6 \mathrm{mg} \mathrm{C}$ $\mathrm{m}^{-2} \mathrm{~d}^{-1}$, respectively).

During March, the pellets of the copepods Pseudocalanus elongatus, Temora longicornis and the appendicularian Fritillaria borealis dominated the sedimented faecal matter. On 14 March we observed a 2-fold increase in the faecal carbon flux within the deep stratum (15 to $30 \mathrm{~m}$ : Fig. 5c,d), coinciding with the highest zooplankton abundance in the subsurface stratum (10 to $20 \mathrm{~m}$ : Table 1, Fig. 3). On the last sampling day, the sedimentation rate of appendicularian faecal pellets was even greater (3.0 mg C $\mathrm{m}^{-2} \mathrm{~d}^{-1}$ at $\left.30 \mathrm{~m}\right)$. Faecal pellets from $P$. elongatus and $T$. longicornis dominated the faecal carbon flux at $30 \mathrm{~m}$ depth (mean $=2.1$ and $2.5 \mathrm{mg} \mathrm{C} \mathrm{m}^{-2} \mathrm{~d}^{-1}$, respectively). Small aggregates, mainly composed of phytoplankton, were common. These aggregates were often attached to an abandoned Fritillaria borealis house. Both disintegrated during analysis and thus were only measured as pigments in traps. 
a)

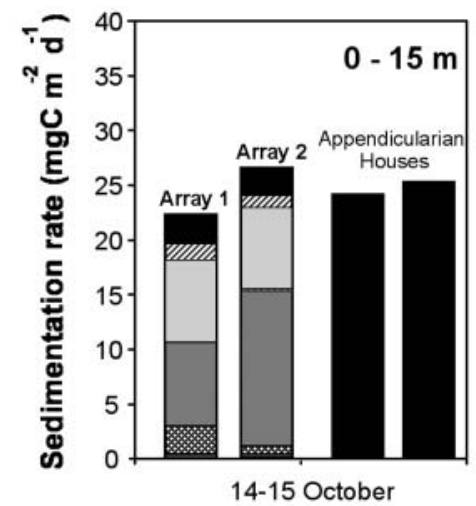

b)

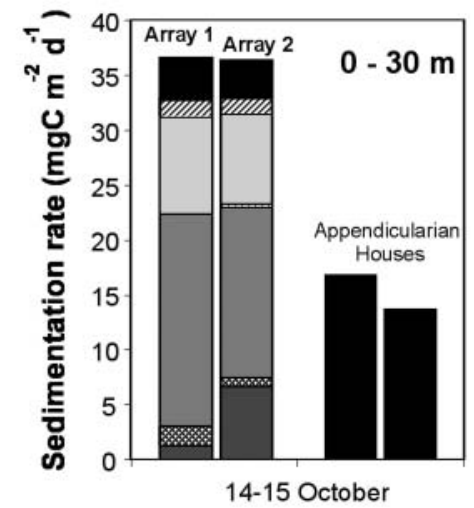

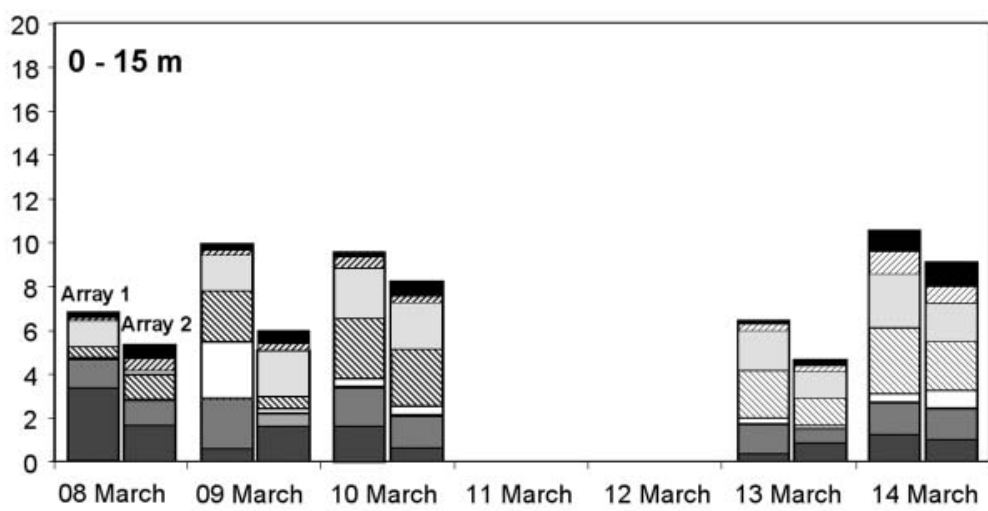

Day in March

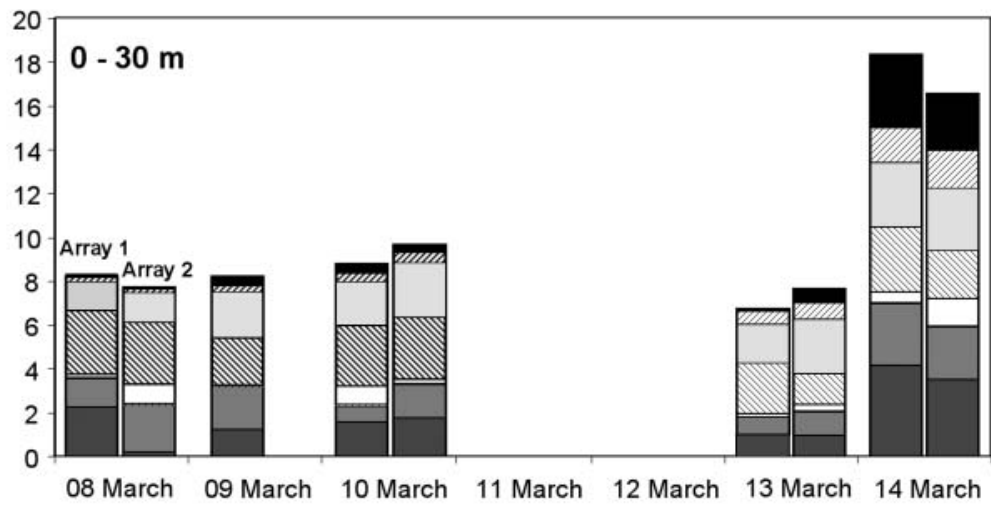

Day in March

Fig. 5. Sedimentation rates of faecal material $\left(\mathrm{mg} \mathrm{C} \mathrm{m}^{-2} \mathrm{~d}^{-1}\right)$ of different origin on 14 and 15 October 1999 (a,b) and from 8 to 14 March 2000 (c, d) at 15 and $30 \mathrm{~m}$. October data also include the biogenic carbon flux due to deserted houses of Oikopleura dioica. Full specific names are given in Table 1
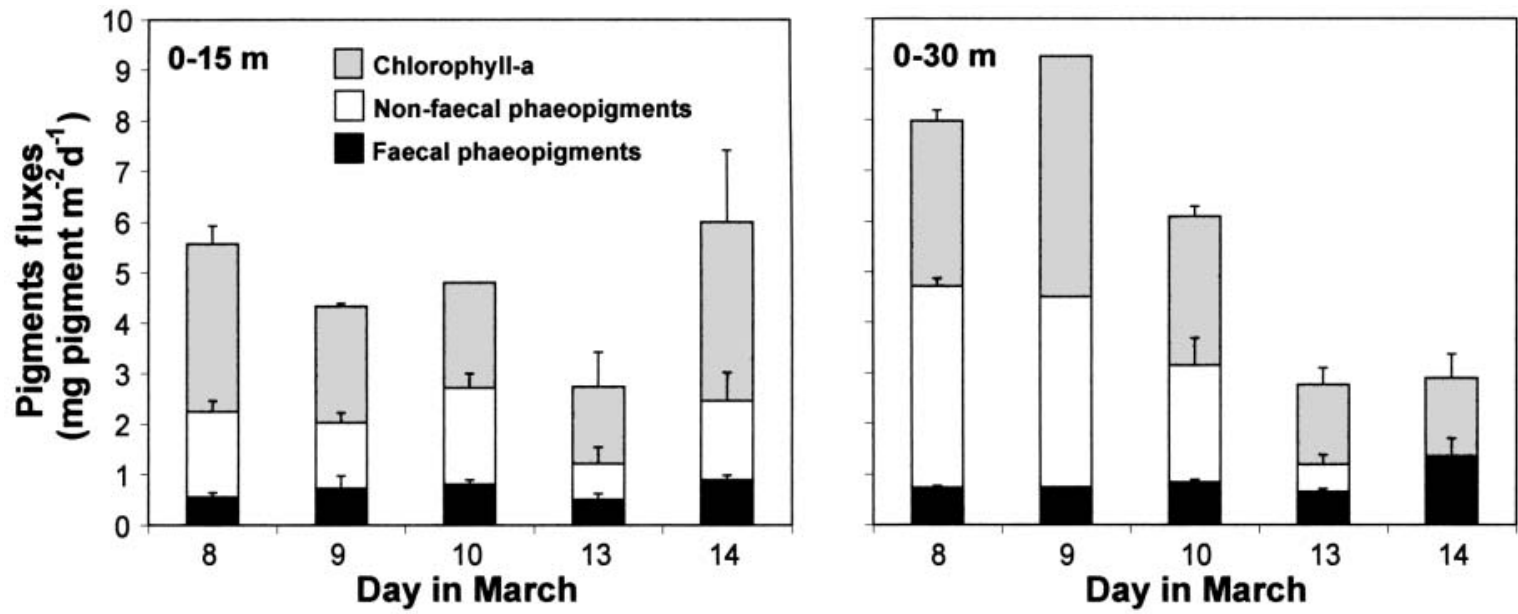

Fig. 6. Chlorophyll $a$ and phaeopigment fluxes at $15 \mathrm{~m}$ (a) and $30 \mathrm{~m}$ (b) in the Gullmar Fjord from 8 to 14 March 2000. Faecal carbon was transformed into phaeopigments assuming a carbon:phaeopigment ratio of 15 (Thibault et al. 1999) to separate faecal and non-faecal phaeopigment origins. Error bars are standard deviations 


\section{Pigments in sediment traps}

In general, pigment fluxes increased with increasing depth (Fig. 6), but differences were not significant (Wilcoxon test; $\mathrm{n}=30 ; \mathrm{p}=0.12$ ). A high variability of fluxes (chl $a+$ phaeopigments) was observed in the $30 \mathrm{~m}$ depth trap in March. High sedimentation of nonfaecal phaeopigments occurred on the first day (8 March), coinciding with a low chl a:phaeopigment ratio in the water column (Fig. 2d). However, on 9 March the contribution of chl a to the pigment fluxes was more important (Fig. 6). Finally, on 14 March we observed a decrease in the deeper chl $a$ and non-faecal phaeopigment fluxes (associated with algal sinking). Therefore, almost all the phaeopigments in the $30 \mathrm{~m}$ sediment traps appear to correspond to the phaeopigments in faecal pellets (Fig. 6). Aggregates collected in the traps suggest that the phytoplankton probably sedimented mainly as small marine snow aggregates or faecal pellets and not as single cells.

\section{DISCUSSION}

\section{Community structure in the water column}

The trophic structure of the heterotroph community is important in determining what fraction of the primary production is exported from the surface to the deep ocean and the sediment. Therefore, vertical carbon fluxes depend as heavily on hydrography, the variations of nutrients, suspended biomass and primary production as on the dynamics of the zooplankton (Wassmann \& Floderus 1995). The present study shows that both zooplankton abundance and biomass were only slightly higher during spring than during the autumn (Wilcoxon test, $\mathrm{n}=43, \mathrm{p}=0.052$ ). In addition, a difference in community structure was observed between both periods. In October, the small copepods Paracalanus parvus and Oithona similis together with the appendicularian Oikopleura dioica were numerically most important in the fjord. In March, the small copepods Temora longicornis, Paracalanus parvus, Pseudocalanus elongatus and Oithona similis, and the appendicularian Fritillaria borealis were common; medium-to-large copepods also contributed a major portion of the total biomass at this time. Abundance of both Oithona similis and Oikopleura dioica were somewhat underestimated in October when a $200 \mu \mathrm{m}$ mesh was used instead of the $90 \mu \mathrm{m}$ mesh net used in March (Krsinic \& Lucic 1994). However, since O. dioica individuals in our samples ranged between 0.6 and $0.8 \mathrm{~mm}$, we assume that only early developmental stages of $O$. dioica could have been lost using a $200 \mu \mathrm{m}$ mesh. The zooplankton abundance was relatively low

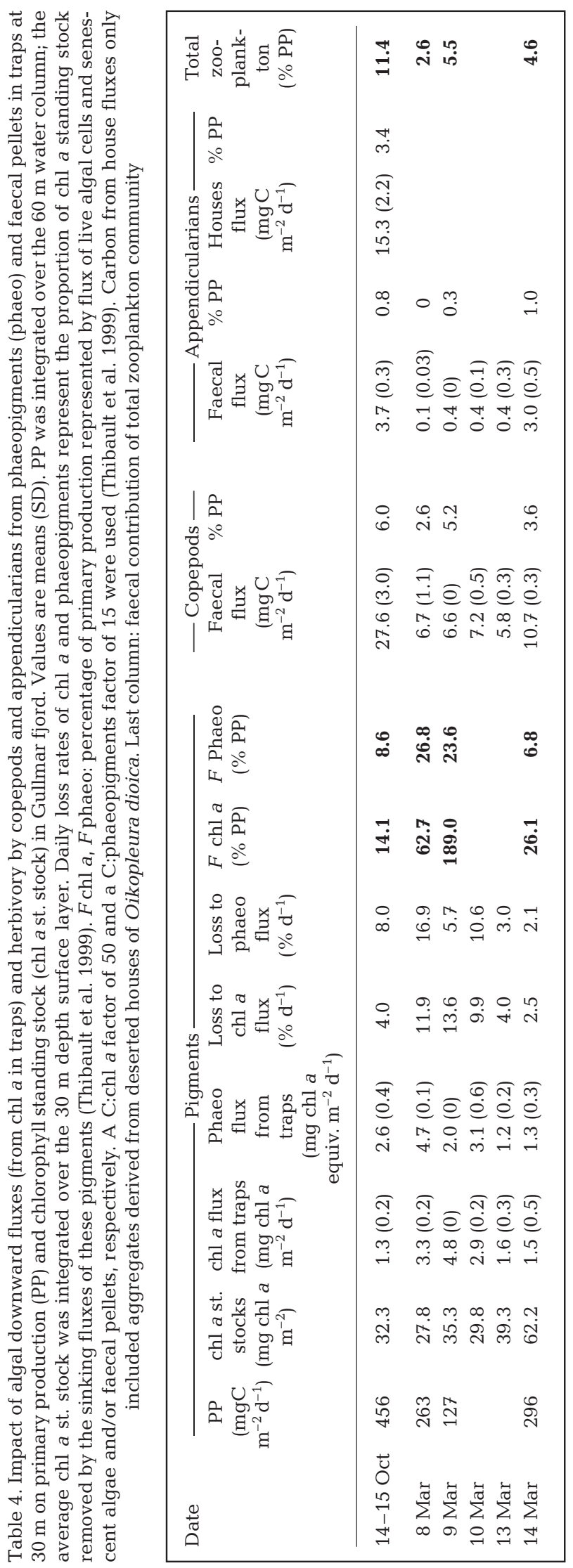


during the few first days in March, but increased in the subsurface layer on 14 March, simultaneously with the increase in phytoplankton biomass (measured as chl a). Neither copepods nor appendicularians (despite the shorter generation times of the latter, e.g. $9.5 \mathrm{~d}$ at 13 to $14^{\circ} \mathrm{C}$ for F. pellucida: Fenaux 1976) could have increased in number within this short period of time. These changes in zooplankton abundance in March were probably due to advective processes, probably by the intrusion of Skagerrak surface water of low temperature (see isoline $4^{\circ} \mathrm{C}, 29.5$ PSU in Fig. 2b,c) and with high nutrients (Lindahl \& Perissinotto 1987).

\section{Production and sedimentation of faecal pellets and appendicularian houses}

Several studies in coastal areas have shown that the zooplankton community structure strongly affects the amount and kind of biogenic carbon available for export (Welschmeyer \& Lorenzen 1985, Wassmann 1998, Roy et al. 2000). The specific contribution to the vertical carbon flux of faecal material produced by different species of copepods and pelagic tunicates is poorly documented. In addition, there are only few studies that take into account both appendicularian faecal pellets and biogenic carbon derived from flocculent appendicularian houses (e.g. Taguchi 1982, Bauerfeind et al. 1997). The present results are derived directly from estimates of faecal pellet and house production and sedimentation.

Our estimates of appendicularian faecal-pellet and house-production rates were consistent with results reported in the literature (mean: 194 pellets ind. ${ }^{-1}$ $\mathrm{d}^{-1}$ and 5 to 19 houses ind. ${ }^{-1} \mathrm{~d}^{-1}$ ) (Fenaux 1985, Hansen et al. 1996, Acuña \& Kiefer 2000, Sato et al. 2001). During October, Oikopleura dioica produced many houses. The carbon flux from aggregates derived from abandoned houses equalled the total copepod faecal flux at 0 to $15 \mathrm{~m}$ and $50 \%$ of it in the 0 to $30 \mathrm{~m}$ sediment traps. In contrast to the faecal pellet flux, we observed a decrease in the flux of house aggregates with increasing depth. To evaluate the daily loss rate of abandoned houses ( $\%$ houses $\mathrm{d}^{-1}$ ) during the transport through the water column, we used our experimental results, whereby $O$. dioica produced 5 houses ind. ${ }^{-1} \mathrm{~d}^{-1}$. Multiplying house-production rate with appendicularian abundance in the water column (0 to $30 \mathrm{~m})$, we arrive at an integrated production of 18900 houses $\mathrm{m}^{-2} \mathrm{~d}^{-1}$, from which only 5800 houses $\mathrm{m}^{-2} \mathrm{~d}^{-1}$ reached the traps. The loss of houses (i.e. approximately $70 \% \mathrm{~d}^{-1}$ ) could be due to several factors, such as physical processes (e.g. advection), trap under-sampling, fragmentation and/or by the activity of detritus-feeding copepods from the genus Corycaeus (Ohtsuka et al. 1993, Gonzalez et al. 2000), which were abundant at that time. Under-sampling seems the least likely of these possibilities, as we did not observe the same loss phenomenon in the $15 \mathrm{~m}$ traps.

When the appendicularian Fritillaria borealis was abundant (13 March), its contribution to the vertical flux of carbon was mainly through faecal pellets. In contrast to Oikopleura dioica, the mucous house produced by F. borealis is 'bubble-like' and, once shed, is very elastic and immediately collapses to the size of a small pellet (Flood \& Deibel 1998, J. L. Acuña pers. comm.). Since the house is relatively small $(2.5 \mathrm{~mm}$; Flood \& Deibel 1998) and aggregation of particles is highly size-dependent, it may not collect many particles while it sinks through the water column. Its small size and thickness also make it more vulnerable to fragmentation or recycling within the surface waters (Pesant et al. 2000). The same argument holds for the small pellets produced by $O$. dioica. We suspect that a large proportion of these pellets may also be recycled in the water column (e.g. Lane et al. 1994, Dagg \& Walser 1986, Small et al. 1987). Our data for larger copepods, however, show that most of the produced pellets were recovered in the traps. A regression of pellets recovered in the traps vs pellets produced (Fig. 7) shows that recycling was significant (ANCOVA; $\mathrm{df}=16 ; \mathrm{p}=0.055$ ), even when only approximately $16 \%$ was recycled (slope: 0.84).

Zooplankton that feed on small cells pack more cells (i.e. mass) per unit pellet volume, resulting in faecal pellets with a higher density (Urban et al. 1993). Even

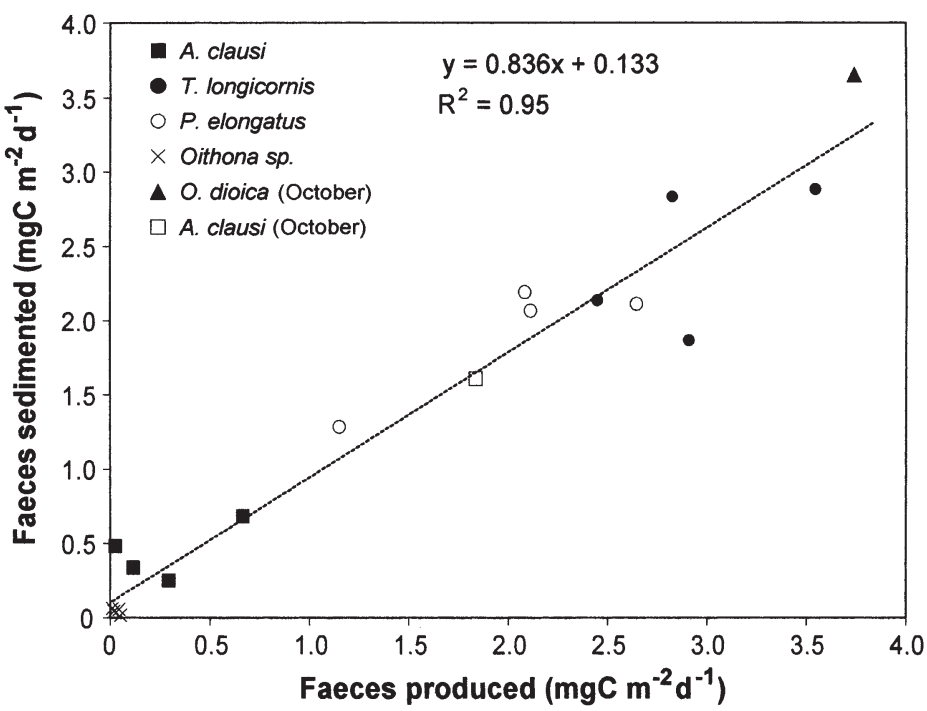

Fig. 7. Comparison between fluxes of faecal pellets from the sediment traps deployed at $30 \mathrm{~m}$ and the integrated rate of production of faecal pellets ( 0 to $30 \mathrm{~m}$ ). Full specific names are given in Table 1 
though the size composition of the particles retained in the appendicularian houses could not be assessed, the results of K. Tönnesson (pers. obs.) reveal that in our study appendicularians were feeding mostly on small flagellates and bacteria. Faeces produced during our experiments were densely packed (Fig. 4a). Therefore, at least during autumn, when Oikopleura dioica was relatively abundant and pico-nanoplankton constituted a significant fraction of the primary producers $(\mathrm{K}$. Tönnesson pers. obs.), compact appendicularian faeces probably had high densities and sinking rates, explaining the high flux of these small faeces (Urban et al. 1992, 1993). Appendicularian grazing thus increases the downward export of small-sized phytoplankton (Pesant et al. 2000). In addition, the total faecal flux increased markedly with increasing depth, suggesting a low degree of recycling by processes such as turnover by zooplankton (Bathmann et al. 1987, Lampitt et al. 1990, Noji et al. 1991). This is typical of many shallow coastal areas, for which increases in flux in deeper compared to shallower traps have been reported (e.g. Smetacek et al. 1978, Bathmann et al. 1987).

Oikopleura dioica faecal carbon flux was comparable to pellet production above the traps but, in contrast, the flux of their houses showed the opposite trend, with a high percentage lost throughout the water column $\left(70 \% \mathrm{~d}^{-1}\right)$. This may be explained by the functional morphology of this appendicularian. Both the spiracles and anus of $O$. dioica are in connection with the posterior chamber (i.e. exit chamber), and thus faecal pellets normally are expelled directly from the house (Fenaux 1986). Pellets of O. dioica therefore add to pellet flux directly and not by sinking with the house. The house sinking rate obviously depends highly on fouling or on the number of pellets remaining in the house. The sinking rate of $O$. longicauda houses in still water may be hundreds of metres per day, but Taguchi (1982) determined that in the field, settling rate was only $7.3 \pm 2 \mathrm{~m} \mathrm{~d}^{-1}$, allowing considerable decomposition to occur during sinking.

Considering the significant contribution to the carbon flux by Oikopleura dioica, despite relatively low biomass (Fig. 3), we conclude that this appendicularian may play an important role in carbon export during the months when it occurs in high numbers (spring and autumn blooms) (Nielsen \& Hansen 1999). This has also been observed in other areas. In the Bjørnafjorden, Norway, González et al. (1994) found that maximum carbon flux due to appendicularian faecal pellets was $7.55 \mathrm{mgC} \mathrm{m}^{-2} \mathrm{~d}^{-1}$ (abundance $=68797$ ind. $\mathrm{m}^{-2}$ ). The same author found that in the Humboldt Current, Chile, maximum carbon flux from appendicularian faecal carbon was $6 \mathrm{mg} \mathrm{C} \mathrm{m}^{-2} \mathrm{~d}^{-1}$ (abundance $=41579$ ind. $\mathrm{m}^{-2}$ : González et al. 2000). Bauerfeind et al. (1997), in the northeast water polynya, observed a flux of appendicularian houses of 0.8 to $5 \mathrm{mgC} \mathrm{m}^{-2} \mathrm{~d}^{-1}$ and faecal carbon fluxes that were similar between copepods and appendicularians $\left(0.35 \mathrm{mg} \mathrm{C} \mathrm{m}^{-2} \mathrm{~d}^{-1}\right)$. In shallow tropical waters, Taguchi (1982) found that larvaceans contributed $66 \pm 6 \%$ to the annual faecal pellet flux volume and houses represented $\sim 60 \%$ of the $450 \mathrm{mg} \mathrm{C} \mathrm{m}^{-2} \mathrm{~d}^{-1}$ of biogenic carbon flux.

Faecal carbon flux from appendicularians observed in these different areas of the world are relatively similar to that reported in the present study. However, our results (Fig. 5) represent the highest contribution by appendicularian houses reported in the literature (14 to $17 \mathrm{mg} \mathrm{C} \mathrm{m}^{-2} \mathrm{~d}^{-1}$ ). Carbon fluxes from appendicularian reported by González et al. $(1994,2000)$ are relatively low compared to the high abundance of appendicularians observed by them. However, these authors only considered the potential contribution of faecal pellets in relatively deep (i.e. 100 to $300 \mathrm{~m}$ ) waters. Clearly, water depth will strongly influence the fate of sinking faecal material and house aggregates in different coastal and oceanic areas, due to the interactions of physical (advection, turbulence) and biological (consumption, mineralization) processes that influence their residence time in the water column. Future studies should therefore include such measurements of residence time as an important factor determining the contribution of appendicularian-mediated fluxes of organic matter.

\section{Algal sinking vs zooplankton-mediated carbon flux}

The sedimentation of the spring bloom constitutes one of the most important mechanisms of vertical flux in boreal waters (Peinert et al. 1989, Olesen \& Lundsgaard 1995). In permanently stratified waters, the bloom coincides with very low temperatures and low grazer abundance, resulting in a high amount of ungrazed phytoplankton sinking to the bottom (Legendre 1990, Kiørboe 1993, Tiselius \& Kuylenstierna 1996). Our results from March show a high short-term variability in faecal carbon flux. Investigations in the Norwegian fjords suggest that herbivorous zooplankters are responsible for such episodic carbon export during the phytoplankton spring bloom (e.g. Wefer 1989), but the general pattern is sinking of ungrazed cells.

During October, the primary production (PP) was $456 \mathrm{mg} \mathrm{C} \mathrm{m}^{-2} \mathrm{~d}^{-1}$, and the fraction of chl a from the upper layer that sedimented daily below the top $30 \mathrm{~m}$ was low and never exceeded $4 \% \mathrm{~d}^{-1}$, or $11.2 \%$ of the PP (Table 4). The percentages of the PP that sedimented due to copepod (6.0\% PP) and appendicularian faecal pellets $(0.8 \% \mathrm{PP})$ correspond well with the percentage of phaeopigments sedimenting ( $8.6 \% \mathrm{PP})$, 
suggesting that phaeopigments sedimented to the bottom primarily through zooplankton faeces rather than as senescent phytoplankton. Appendicularian houses accounted for a significant contribution of the total biogenic carbon flux (3.4\% of the PP), increasing the total zooplankton-mediated carbon flux to $11.4 \%$ of the PP. Even so, during October, only a small fraction of the primary production was exported to the bottom and $>85 \%$ of the primary production was available to other pelagic processes.

In March, PP was variable (127 to $296 \mathrm{mg} \mathrm{C} \mathrm{m}^{-2} \mathrm{~d}^{-1}$ ) but always lower than in October (Table 4). From 8 to 10 March, the proportion of surface chl a that sedimented daily sometimes exceeded $10 \% \mathrm{~d}^{-1}$. Associated with this high chl a flux, the loss of phaeopigments was also high (5.7 to $16.9 \% \mathrm{~d}^{-1} ; 12.8$ to $23.6 \%$ of the PP). Considering the low faecal pellets flux (1.4 to $5.5 \%$ of the PP), most of these phaeopigments probably sedimented as senescent algae. In addition, the percentage of the PP that sedimented as live cells (measured as chl a) was also high, with a maximum value on 9 March exceeding $189 \%$ of the PP (Table 4). This high chl a flux suggests that a large proportion of the primary production (63 to 189\%) was rapidly sinking ungrazed from the upper layer. In fact, we observed abundant phytoplankton aggregates in the sediment traps during this period. It should be noticed that neither the chl a nor PP was indicative of a spring bloom, when values are typically 10 times higher (e.g. Lindahl 1990). Therefore, the contribution from faecal material was higher than usual in our study. Aggregation of diatoms into large, rapidly sinking aggregates has been observed as an important mechanism facilitating the phytoplankton fallout (Smetacek 1985), particularly during periods when the abundance of grazers is low, as during our study (Jackson 1990, Hill 1992). Tiselius \& Kuylenstierna (1996) found rapid physical aggregation (through windgenerated turbulence) and sedimentation of phytoplankton in Gullmar Fjord during a similar period of the year, supporting the interpretation that cell aggregation is important for the sedimentation of intact cells in this area when grazer abundance is low. On 14 March, chl a and phaeopigments fluxes decreased and faecal flux increased (Fig. 5), probably as a response to the increase in zooplankton biomass (Fig. 3). At their maximal abundance Fritillaria borealis accounted for ca. $20 \%$ of the total zooplankton faecal flux.

\section{CONCLUSIONS}

This study has shown that zooplankton community structure has an important effect on the relative contribution of faecal material to the flux of particulate organic carbon. Different species composition and probably different grazing activity during spring and autumn contributed to differences in the ratio of export to production in this system.

Almost all the faecal matter produced in the water column was efficiently exported to the sea floor. Appendicularians played an important role in the zooplankton-mediated export of biogenic carbon through faecal pellets and abandoned houses. During the autumn, the abandoned houses of Oikopleura dioica contributed significantly to the downward flux of biogenic carbon, although the appendicularian biomass was lower than during spring. In contrast, houses of the 'spring appendicularian' Fritillaria borealis were not identified in the downward flux, and these are probably recycled in the water column, or perhaps sediment as unidentifiable compact aggregates enriched with faecal pellets, phytoplankton and bacterial cells. Either way, it is clear that all appendicularians do not have the same impact on biogeochemical cycles.

Acknowledgements. We acknowledge the skilful help of the captain and crew of the RV 'Arne Tiselius'. We are very grateful to Don Deibel (Memorial University of Newfoundland, Canada) and Jose Luis Acuña (Universidad de Oviedo, Spain) for constructive comments on an earlier version of the manuscript. We also thank 3 anonymous reviewers for their very helpful remarks. Thanks to M. Kuylenstierna for help with obtaining photographs. The Large Scale Facility Program EU, provided funding for the laboratory and field activities at Kristineberg Marine Research Station (KMF) during the study periods. The present investigation was supported by the EU MAST III programme contract MAS3-CT97-0148-KEYCOP and The Danish National Research Council contract no. 9801391. C.V. was supported by a Swedish Institute fellowship at KMF in Sweden and by a CONICYT doctoral fellowship during the preparation of the manuscript in Chile. Additional support from the Fondecyt 1000419 is acknowledged. Escuela de Graduados, Universidad de Concepcion, provided additional travel support to C.V.

\section{LITERATURE CITED}

Acuña JL, Kiefer M (2000) Functional response of the appendicularian Oikopleura dioica. Limnol Oceanogr 45:608-618

Acuña JL, Bedo AW, Harris RP, Anadon R (1995) The seasonal succession of appendicularians (Tunicata: Appendicularia) off Plymouth. J Mar Biol Assoc UK 75:755-758

Acuña JL, Deibel D, Morris CC (1996) Particle capture mechanism of the pelagic tunicate Oikopleura vanhoeffeni. Limnol Oceanogr 41:1800-1814

Alldredge AL (1992) Marine snow in oceanic cycling. Encycl Earth Syst Sci 3:139-147

Alldredge AL (1998) The carbon, nitrogen and mass content of marine snow as a function of aggregate size. Deep-Sea Res 45:529-545

Alldredge AL, Gotschalk C (1988) In situ settling behaviour of marine snow. Limnol Oceanogr 21:14-23

Alldredge AL, Gotschalk C (1990) The relative contribution of marine snow of different origins to biological processes in coastal waters. Cont Shelf Res 10:41-58 
Alldredge AL, Silver MW (1988) Characteristics, dynamics and significance of marine snow. Prog Oceanogr 20:41-82

Bathmann UV, Noji TT, Voss M, Peinert R (1987) Copepod faecal pellets: abundance, sedimentation and content at a permanent station in the Norwegian Sea in May/June 1986. Mar Ecol Prog Ser 38:45-51

Bauerfeind E, Garrity C, Krumbholz M, Ramseier RO, Voß M (1997) Seasonal variability of sediment trap collections in the northeast water polynya. Part 2. Biochemical and microscopic composition of sedimenting matter. J Mar Syst 10:371-389

Booth BC, Lewin J, Postel JR (1993) Temporal variation in the structure of autotrophic and heterotrophic communities in the Subarctic Pacific. Progr Oceanogr 32:57-99

Dagg MJ, Walser WE Jr (1986) The effect of food concentration on faecal pellet size in marine copepods. Limnol Oceanogr 31:1066-1071

Deibel D (1988) Filter feeding by Oikopleura vanhoeffeni: grazing impact on suspended particles in cold ocean waters. Mar Biol 99:177-186

Deibel D, Lee SH (1992) Retention efficiency of submicrometer particles by the pharyngeal filter of the pelagic tunicate Oikopleura vanhoeffeni. Mar Ecol Prog Ser 81:25-30

Fenaux R (1976) The appendicularians. In: Steadman HF (ed) Monographs on oceanographic methodology. UNESCO Press, Paris, p 309-312

Fenaux R (1985) Rhythm of secretion of oikopleurid's houses. Bull Mar Sci 37:498-503

Fenaux R (1986) The house of Oikopleura dioica (Tunicata, Appendicularia): structure and functions. Zoomorphology (Berl) 186:224-231

Flood PR, Deibel D (1998) The appendicularian house. In: Bone Q (ed) The biology of pelagic tunicates. Oxford University Press, Oxford, p 105-124

González HE (1992) Distribution and abundance of minipellets around the Antarctic peninsula. Implications for protistan feeding behaviour. Mar Ecol Prog Ser 90:223-236

González HE, Smetacek V (1994) The possible role of the cyclopoid Oithona in retarding vertical flux of zooplankton faecal material. Mar Ecol Prog Ser 105:31-45

González HE, González S, Brummer GJ (1994) Short-term sedimentation pattern of zooplankton, faeces and microplankton at a permanent station in the Bjørnafjorden (Norway) during April-May 1992. Mar Ecol Prog Ser 105: 31-45

González HE, Ortiz V, Sobarzo M (2000) The role of faecal material in the particulate organic carbon flux in the northern Humboldt Current, Chile $\left(23^{\circ} \mathrm{S}\right)$, before and during the 1997-1998 El Niño. J Plankton Res 22:499-529

Gorsky G, Dallot S, Sardou J, Fenaux R, Carré C, Palazzoli I (1988) C and N composition of some northwestern Mediterranean zooplankton and micronekton species. J Exp Mar Biol Ecol 124:133-144

Gorsky G, Flood PR, Youngbluth M, Picheral M, Grisoni JM (2000) Zooplankton distribution in four western Norwegian fjords. Estuar Coast Shelf Sci 50:129-135

Gowing MM, Silver MW (1985) Minipellets: a new and abundant size class of marine faecal pellets. J Mar Res 43: 395-418

Hansen JLS, Kiørboe T, Alldredge AL (1996) Marine snow derived from abandoned larvacean houses: sinking rates, particle content and mechanisms of aggregate formation. Mar Ecol Prog Ser 141:202-215

Hill P (1992) Reconciling aggregation theory with observed vertical fluxes following phytoplankton blooms. J Geophys Res 97:2295-2308

Hopcroft RR, Roff JC (1995) Zooplankton growth rates: extra- ordinary production by the larvacean Oikopleura dioica in tropical waters. J Plankton Res 17:205-220

Hopcroft RR, Roff JC (1998) Production of tropical larvaceans in Kingston Harbour, Jamaica: are we ignoring an important secondary producer? J Plankton Res 20:557-569

Hopcroft RR, Roff JC, Bouman HA (1998) Zooplankton growth rates: the larvaceans Appendicularia, Fritillaria and Oikopleura in tropical waters. J Plankton Res 20:539-555

Jackson GA (1990) A model of the formation of marine algal flocs by physical coagulation processes. Deep-Sea Res 37: $1197-1211$

Jespersen AM, Christoffersen K (1987) Measurements of chlorophyll a from phytoplankton using ethanol as extraction solvent. Arch Hydrobiol 109:445-454

King KR, Hollibaugh JT, Azam F (1980) Predator-prey interactions between the larvacean Oikopleura dioica and bacterioplankton in enclosed water columns. Mar Biol 56: $49-57$

Kiørboe T (1993) Turbulence, phytoplankton cell size and the structure of pelagic food webs. Adv Mar Biol 29:1-72

Kiørboe T, Lundsgaard C, Olesen M, Hansen JLS (1994) Aggregation and sedimentation processes during a spring phytoplankton bloom: a field experiment to test coagulation theory. J Mar Res 52:297-323

Krsinic F, Lucic D (1994) Mesozooplankton sampling experiments with the 'Adriatic' sampler: differences of catch between 250 and $125 \mu \mathrm{m}$ mesh netting gauze. Estuar Coast Shelf Sci 38:113-118

Lampitt RS, Noji TT, von Bodungen B (1990) What happens to zooplankton faecal pellets? Implications for material flux. Mar Biol 104:15-23

Landry MR, Lorenzen CJ, Peterson WK (1994) Mesozooplankton grazing in the Southern California Bight. II. Grazing impact and particulate flux. Mar Ecol Prog Ser 115:73-85

Lane PVZ, Smith SL, Urban JL, Biscaye PE (1994) Carbon flux and recycling associated with zooplanktonic faecal pellets on the shelf of the Middle Atlantic Bight. Deep-Sea Res Part II Top Stud Oceanogr 41:437-457

Legendre L (1990) The significance of microalgal blooms for fisheries and for the export of particulate organic carbon in the ocean. J Plankton Res 12:681-699

Legendre L, Rassoulzadegan F (1996) Food-web mediated export of biogenic carbon in the oceans: hyrodynamic control. Mar Ecol Prog Ser 145:179-193

Lindahl O (1990) Dynamics and sedimentation of algal blooms in the Güllmar Fjord in 1988. In: Wassmann P, Heiskanen AS, Lindahl O (eds) Sediment trap studies in the nordic countries. Proc Symp 'Sediment traps in marine ecological research and monitoring'. Nurmi Print OY, Hanko, p 190-202

Lindahl O (1995) Long-term studies of primary phytoplankton production in the Güllmar fjord, Sweden. In: Skjoldal C, Hopkins K, Erikstad E, Leinaas HP (eds) Ecology of fjords and coastal waters. Elsevier, Amsterdam, p 105-112

Lindahl O, Perissinotto R (1987) Short-term variations in the zooplankton community related to water exchange processes in the Gullmar fjord, Sweden. J Plankton Res 9: $1113-1132$

López-Urrutia Á, Acuña JL (1999) Gut throughput dynamics in the appendicularian Oikopleura dioica. Mar Ecol Prog Ser 191:195-205

Newton Downs J, Lorenzen CJ (1985) Carbon:phaeopigment ratios of zooplankton faecal pellets as an index of herviborous feeding. Limnol Oceanogr 30:1024-1036

Nielsen TG, Hansen PJ (1999) Dyreplankton I danske farvande. Miljø- og Energiministeriet, Danmarks Miløundersøgelser (in Danish) 
Noji TT, Estep K, MacIntyre F, Norrbin F (1991) Image analysis of faecal material grazed upon by three species of copepods. Evidence for coprophagy, coprorhexy and coprochaly. J Mar Biol Assoc UK 71: 465-480

Ohtsuka S, Kubo N, Okada M, Gushima K (1993) Attachment and feeding of pelagic copepods on larvacean houses. J Oceanogr Soc Jpn 49:115-120

Olesen M, Lundsgaard C (1995) Seasonal sedimentation of autochthonous material from the euphotic zone of a coastal system. Estuar Coast Shelf Sci 41:475-490

Paffenhöfer GA (1976) On the biology of Appendicularia of the southern North Sea. In: Persoone G, Jaspers E (eds) Proc 10th Eur Symp Mar Biol. Universa Press, Wetteren, p 437-455

Peinert R, von Bodungen B, Smetacek V (1989) Food web structure and loss rate. In: Berger WH, Smetacek VS, Wefer G (eds) Productivity of the ocean: present and past. John Wiley \& Sons, New York, p 35-48

Pesant S, Legendre L, Gosselin M, Bjornsen PK, Fortier L, Michaud J, Nielsen TG (2000) Pathways of carbon cycling in marine surface waters: the fate of small-sized phytoplankton in the northeast water polynya. J Plankton Res 22:779-801

Petersen GH, Curtis MA (1980) Differences in energy flow through major components of the subarctic, temperate and tropical marine shelf ecosystems. Dana 1:53-64

Roy S, Silverberg N, Romero N, Deibel D and 6 others (2000) Importance of mesozooplankton feeding for the downward flux of biogenic carbon in the Gulf of St. Lawrence (Canada). Deep-Sea Res Part II 47:529-544

Sato R, Tanaka Y, Ishimaru T (2001) House production by Oikopleura dioica (Tunicata, Appendicularia) under laboratory conditions. J Plankton Res 23:415-423

Small LF, Knauer GA, Tuel MD (1987) Sinking rates of natural copepod faecal pellets. Mar Biol 51:233-241

Smetacek VS (1985) Role of sinking in diatom life-history cycles: ecological, evolutionary and geological significance. Mar Biol 84:239-251

Smetacek VS, von Bröckel K, Zeitschel B, Zenk W (1978) Sedimentation of particulate matter during a phytoplankton spring bloom in relation to the hydrographical regime. Mar Biol 47:211-226

Strickland JDH, Parsons TR (1968) A practical handbook of seawater analysis. Bull Fish Res Board Can 167:1-311

Editorial responsibility: Michael Landry (Contributing Editor), Honolulu, Hawaii, USA
Syvitiski JPM, Asprey KW, Leblanc KWG (1995) In situ characteristics of particles settling within a deepwater estuary. Deep-Sea Res 42:223-256

Taguchi S (1982) Seasonal study of faecal pellets and discarded houses of Appendicularia in a subtropical inlet, Kaneohe Bay, Hawaii. Estuar Coast Shelf Sci 14: 545-555

Thibault D, Roy S, Wong, CS, Bishop JK (1999) The downward flux of biogenic material in the NE subarctic Pacific: importance of algal sinking and mesozooplankton hervibory. Deep-Sea Res Part II 46:2669-2697

Tiselius P, Kuylenstierna M (1996) Growth and decline of a diatom spring bloom: phytoplankton species composition, formation of marine snow and the role of heterotrophic dinoflagellates. J Plankton Res 18:133-155

Urban JL, McKenzie CH, Deibel D (1992) Seasonal differences in the content of Oikopleura vanhoeffeni and Calanus finmarchicus faecal pellets: illustrations of plankton food web shifts in coastal Newfoundland waters. Mar Ecol Prog Ser 84:255-264

Urban JL, Deibel D, Schwinghamer P (1993) Seasonal variations in the densities of faecal pellets produced by Oikopleura vanhoeffeni (C. Larvacea) and Calanaus finmarchicus (C. Copepoda). Mar Biol 117:607-613

Walsh ID, Gardner WD (1992) A comparison of aggregate profiles with sediment trap fluxes. Deep-Sea Res 39: $1817-1834$

Wassmann P (1998) Pelagic retention versus export food chains: processes controlling sinking loss from marine pelagic systems. Hydrobiologia 363:29-57

Wassmann P, Floderus S (1995) Introduction: seasonal dynamics of planktonic ecosystems and sedimentation in coastal Nordic waters. In: Floderus S, Heiskanen AS, Olesen M, Wassmann P (eds) Sediment trap studies in the nordic countries 3, Symp Proc. Nurmi Print OY, Helsinki, p $1-27$

Wefer G (1989) Particle flux in the ocean: effects of episodic production. In: Berger WH, Smetacek, VS, Wefer G (eds) Productivity of the ocean: present and past. John Wiley \& Sons Ltd, New York, p 139-153

Welschmeyer NA, Lorenzen CJ (1985) Chlorophyll budgets: zooplankton grazing and phytoplankton growth in a temperate fjord and the Central Pacific Gyres. Limnol Oceanogr 30:1-21

Submitted: June 28, 2001; Accepted: May 13, 2002

Proofs received from author(s): September 9, 2002 